\title{
Consumption of Alzheimer disease protective nutrients in diets of polish elderly divided into different nutritional status (MNA)
}

\author{
Joanna Wyka*, Jadwiga Biernat \\ Department of Human Nutrition, Wroclaw University of Environmental and Life Sciences, Wroclaw, Poland; \\ *Corresponding Author: Joanna.Wyka@up.wroc.pl
}

Received 13 August 2012; revised 10 September 2012; accepted 18 September 2012

\begin{abstract}
Many abnormalities can be observed in the nutrition of elderly people which, as a consequence, lead to occurrence or progression of many already existing diet-dependent diseases. The aim of this work was assessment of nutrients consumption, important for prevention and treatment of diet-dependent diseases and potentially neuropsychological diseases, including Alzheimer disease. The intake of antioxidant vitamins, group B vitamins and polyunsaturated fatty acids in food ratios was assessed among 1001 people over 60 years of age, from Wroclaw and nearby areas, SW Poland. Selected parameters of lipid and carbohydrate metabolism were determined in the blood of surveyed people. A deficit intake of all nutrients was demonstrated in groups distinguished by MNA form. Moreover, it was demonstrated that statistically significant, the lowest amounts of vitamin A, E, C, B6, B12, folates, and many other polyunsaturated fatty acids were consumed by women at risk of malnutrition in comparison with women with an adequate nutritional status. Statistically significant lower biochemical parameters, such as TC, LDL TG and glucose were also demonstrated in the group of women at risk of malnutrition than in the group of women with an adequate nutriational status. Control and supervision of the elderly persons' nutritional intake constitutes the basis of the assessment of risk of deficiency of particular nutritional components occurrence and negative health effects deriving from it. Poor nutrition of seniors along with longer life, from demographic point of view, induces to search for new efficient health-oriented strategies.
\end{abstract}

Keywords: Elderly; Nutrients; Nutritional Status
(MNA); Alzheimer Disease

\section{INTRODUCTION}

Good nutrition in the elderly acts as a protection against chronic diseases. Nutrients, consumed in an adequate amount, support the body in adaptive processes that become defective over time. Good nutrition is an important element of the lifestyle that can become a protective factor, promoting successful aging. It has been shown that the aging period can be delayed by regulation of the way of life, proper diet, physical and mental abilities maintenance. The man's nutrition has to supply the organism with all the food ingredients which are indispensable to its proper functioning. Te way the need of nutrition is satisfied, that is the way of feeding and the health quality of food is not left without the influence on the health condition of the individual. The state of nutrition as well as health and the man's mood influence the physical and mental development to a significant extent. The inseparable condition of health and the man's good mood is varied, regular and moderate as well as balanced diet, as regards quantity and quality, which is adjusted to the age, the gander, the health condition and the life style. The proper course of metabolic processes depends on the proper supply of material, energetic and regulating components.

Involutional physiological changes that arise over time are overlapping by diet-dependent diseases associated with dysfunction of, for example, the cardiovascular system, which significantly impair functions of all organs and tissues.

Undoubtedly inadequate nutrition, resulting from inadequate nutrients intake from food sources, their poor absorption and use and influence of external pathologic factors, is among other the medium for arteriosclerosis, arterial hypertension, diabetes, cancers and other diseases $[1,2]$.

Inadequate nutrition habits and customs observed 
among elderly people, established during childhood and strengthened in adolescence, as well as, the need to avoid some products from different reasons, have many medical consequences, in particular nutrients deficiency and malnutrition. Although data regarding effects of nutrition factors on man's cognitive functions, including Alzheimer's disease (AD), are not completely known, it seems that promoting balanced nutrition in the society (for example in the form of food guide pyramid) since childhood can delay for a few years a development of diseases associated with dysfunction of cognitive functions [3-5]. AD is complex, slowly progressive neurodegenerative disorder of brain and is the most common form of dementia, followed by vascular dementia, and mixed dementia. Progressive cognitive decline is often accompanied by affective, behavioural disturbances, also termed neuropsychiatric symptoms, for example: depression, apathy, agitation, aggressiveness, delusions and hallucinations, anxiety, abnormal motor behaviour and day-night reversal. Neuropsychological diseases are classified as chronic diseases of aetiology that is still controversial. Nowadays searching for protective factors in their aetiology has a crucial role [2]. It is assumed that some nutritional factors such as proper intake of antioxidant vitamins, vitamins from group B and polyunsaturated fatty acids can play a crucial role in their prevention and treatment $[2,4,6]$.

\section{METHODS}

\subsection{Subjects}

In collaboration with the Institute of Public Health in Wroclaw and the Oleśnica district, in the Lower Silesia Voivodship, SW Poland all persons over the age of 60 (n $=1001$ ) based on the Personal Identification Number and inhabiting one of the districts of the city of Wroclaw were included. Every person received a written invitation (by letter) to a free-of charge prophylactic programme "Health of a Senior". Each of them was informed about the objective of the study and nutritional, anthropometric and biochemical methods. The study was approved by Bioethical Commission at the Medical University in Wroclaw (approval No. 509/2008). The characteristic of group was presented in Table 1.

\subsection{Nutritional Assessment and MNA}

The evaluation of nutritional patterns of the elderly was conducted with the method of 24-h dietary recall. Contents of nutrients and groups of food products in everyday food rations were calculated using computer software, "Energia" (2006), with the database of the National Institute of Food and Nutrition in Warsaw [7]. Intake of nutrients was compared with polish nutritional norms and recommendations for persons over 60 years of age [8].

The MNA is specially designed and valid for geriatric patients and can be performed in less than $10 \mathrm{~min}$. It is composed of anthropometric measurements which were analyzed by anthropometer with accuracy exact to 0.1 $\mathrm{cm}$ and electronic scale (body mass, $0.1 \mathrm{~kg}$ ). During measurements, the subjects were without shoes and in light clothing. The Body Mass Index (BMI) was computed according to the formula: body mass/body height ${ }^{2}$. In general assessment, questions were related to lifestyle, medication, mobility and neuropsychological problems. Dietary questionnaire consisted of number of meals, protein, fruits and vegetables, fluid intake and autonomy of feeding. Subjective assessment based on self-perception of health and own nutrition. Each response was assessed according to the number of points, maximum 30 . The sum of the MNA score distinguishes between elderly patients with adequate nutritional status (MNA $>24$ points), at risk of malnutrition (MNA 17 - 23.5) and malnutrition (MNA < 17) $[9,10]$. The results of study were presented in Table 2.

\subsection{Clinical Chemistry Parameters}

A 12-hour fasting blood sample was draw from each participant in the morning. The concentration of total cholesterol in blood serum was assayed with the cholesterol oxidase (CHO) and peroxidase (POD) method; the concentration of HDL cholesterol in serum with the spectrophotometric method using an Olympus analyzer and antibodies against human beta-lipoproteins, cholesterol esterase (CHE), CHO, POD, and ascorbate oxidase; the concentration of LDL cholesterol in plasma was calculated from the Friedewald's formula; the concentration of serum triglycerides was determined with an enzymatic test by Olympus (spectrophotometric method) using bacterial lipases and POD; whereas the concentration of glucose was assayed with an Olympus analyzer (spectrophotometric method) using a hexokinase (HK) method. Reference ranges of the results obtained were adopted following guidelines of the National Cholesterol Education Program Expert Panel on Detection, Evaluation and Treatment of High Blood Cholesterol in Adults (Adults Treatment Panel III) [11]. Date was presented in Table 3.

\subsection{Statistical Analysis}

Statistical analyses were done with a Statistica 8.0 Package. A Chi-square test was used to compare social and demographic variables in the examined group. Nutritional data was first tested for normal distribution by using Shapiro-Wilk's test for normality. Because not all variables were normally distributed, the unpaired MannWhitney rank sum test was used to evaluate differences between different groups of nutritional status. Results are 
Table 1. Characteristic of the participants elderly men and women divided into different nutritional status (MNA) n, n (\%).

\begin{tabular}{|c|c|c|c|c|}
\hline & \multirow{2}{*}{ Parameters } & \multicolumn{3}{|c|}{ MNA } \\
\hline & & Risk of malnutrition $n=63$ & Adequate nutritional status $\mathrm{n}=938$ & $\mathrm{p}$ \\
\hline \multirow{3}{*}{ Sex } & Women & $45(71.4 \%)$ & $585(62.3 \%)$ & \multirow{2}{*}{0.14} \\
\hline & Men & $18(28.5 \%)$ & $353(37.6 \%)$ & \\
\hline & Wroclaw & $19(30.1 \%)$ & $476(50.7 \%)$ & \multirow{3}{*}{0.00} \\
\hline \multirow[t]{3}{*}{ Accomodation } & Small city & $19(30.1 \%)$ & $249(26.5 \%)$ & \\
\hline & Village & $25(39.6 \%)$ & $213(22.7 \%)$ & \\
\hline & $60-65$ & $10(15.8 \%)$ & $287(30.6 \%)$ & \multirow{3}{*}{0.02} \\
\hline \multirow{2}{*}{ Age (years) } & $66-75$ & $26(41.2 \%)$ & $365(38.9 \%)$ & \\
\hline & $>75$ & $27(42.8 \%)$ & $286(30.4 \%)$ & \\
\hline \multirow{5}{*}{ Education } & Elementary & $28(44.4 \%)$ & $345(36.7 \%)$ & \multirow{5}{*}{0.00} \\
\hline & Vocational & $4(6.3 \%)$ & $161(17.1 \%)$ & \\
\hline & Secondary & $20(31.7 \%)$ & $286(30.4 \%)$ & \\
\hline & University & $4(6.3 \%)$ & $128(13.6 \%)$ & \\
\hline & other & $7(11.1 \%)$ & $18(1.9 \%)$ & \\
\hline \multirow{4}{*}{$\begin{array}{l}\text { Economic status } \\
(1 \text { euro }=3.3 \text { pln })\end{array}$} & $<500$ pln & $1(1.5 \%)$ & $9(0.9 \%)$ & \multirow{4}{*}{0.79} \\
\hline & $501-700$ pln & $11(17.4 \%)$ & $127(13.5 \%)$ & \\
\hline & $701-1000 \mathrm{pln}$ & $18(28.5 \%)$ & $277(29.5 \%)$ & \\
\hline & $>1001 \mathrm{pln}$ & $33(52.3 \%)$ & $525(55.9 \%)$ & \\
\hline \multirow{4}{*}{ Type of family } & Single & $11(17.4 \%)$ & $214(22.8 \%)$ & \multirow{4}{*}{0.53} \\
\hline & Single with help of other people & $4(6.3 \%)$ & $40(4.2 \%)$ & \\
\hline & With a spouse, with children & $44(69.8 \%)$ & $647(68.9 \%)$ & \\
\hline & With other family member & $4(6.3 \%)$ & $37(3.9 \%)$ & \\
\hline \multirow{3}{*}{ Shopping } & Independently & $40(63.4 \%)$ & $693(73.8 \%)$ & \multirow{3}{*}{0.04} \\
\hline & With family help & $23(36.5 \%)$ & $229(24.4 \%)$ & \\
\hline & With help of other people & $0(0.0 \%)$ & $16(1.7 \%)$ & \\
\hline
\end{tabular}

Comparison with $x^{2}$-test, $\mathrm{p}<0.05$.

Table 2. Nutrients in elderly food ratios divided into sex and MNA $(\mathrm{n}=1001)$.

\begin{tabular}{|c|c|c|c|c|c|c|c|c|c|c|}
\hline \multirow{3}{*}{ Nutrients } & \multirow{3}{*}{$\begin{array}{c}\text { Nutrition } \\
\text { norms }\end{array}$} & \multicolumn{4}{|c|}{ Women $(n=630)$} & \multicolumn{5}{|c|}{$\operatorname{Men}(n=371)$} \\
\hline & & \multicolumn{2}{|c|}{$\begin{array}{c}\text { At risk of } \\
\text { malnutrition }(n=45)\end{array}$} & \multicolumn{2}{|c|}{$\begin{array}{l}\text { Adequate nutritional } \\
\text { status }(\mathrm{n}=585)\end{array}$} & \multirow{2}{*}{$\begin{array}{c}\text { Nutrition } \\
\text { norms }\end{array}$} & \multicolumn{2}{|c|}{$\begin{array}{c}\text { At risk of } \\
\text { malnutrition }(n=18)\end{array}$} & \multicolumn{2}{|c|}{$\begin{array}{l}\text { Adequate nutritional } \\
\text { status }(\mathrm{n}=353)\end{array}$} \\
\hline & & $\begin{array}{l}\mathrm{Me} \pm \mathrm{QD} \\
(\% \text { norm })\end{array}$ & $\begin{array}{l}\text { Q1 } \\
\text { Q3 }\end{array}$ & $\begin{array}{l}\mathrm{Me} \pm \mathrm{QD} \\
(\% \text { norm })\end{array}$ & $\begin{array}{l}\text { Q1 } \\
\text { Q3 }\end{array}$ & & $\begin{array}{l}\mathrm{Me} \pm \mathrm{QD} \\
(\% \text { norm })\end{array}$ & $\begin{array}{l}\text { Q1 } \\
\text { Q3 }\end{array}$ & $\begin{array}{l}\mathrm{Me} \pm \mathrm{QD} \\
(\% \text { norm })\end{array}$ & $\begin{array}{l}\text { Q1 } \\
\text { Q3 }\end{array}$ \\
\hline Vitamin A (mcg) & $500^{1}$ & $\begin{array}{c}\mathrm{a} 360.2 \pm 190.5 \\
(72.0 \%)\end{array}$ & $\begin{array}{l}206.6 \\
587.7\end{array}$ & $\begin{array}{c}{ }^{\mathrm{b}} 477.9 \pm 214.5 \\
(95.5 \%)\end{array}$ & $\begin{array}{l}297.3 \\
726.3\end{array}$ & $630^{1}$ & $\begin{array}{c}497.6 \pm 233.1 \\
(78.9 \%)\end{array}$ & $\begin{array}{l}324.3 \\
791.2\end{array}$ & $\begin{array}{c}765.9 \pm 359.1 \\
(121.5 \%)\end{array}$ & $\begin{array}{l}212.5 \\
931.2\end{array}$ \\
\hline Vitamin E (mg) & $8^{3}$ & $\begin{array}{l}\mathrm{a}_{5} 5.1 \pm 2.4 \\
(63.7 \%)\end{array}$ & $\begin{array}{l}2.9 \\
7.9\end{array}$ & $\begin{array}{l}{ }^{\mathrm{b}} 6.4 \pm 2.5 \\
(80.0 \%)\end{array}$ & $\begin{array}{l}3.9 \\
9.2\end{array}$ & $10^{3}$ & $\begin{array}{l}7.3 \pm 2.5 \\
(73.0 \%)\end{array}$ & $\begin{array}{c}4.8 \\
10.2\end{array}$ & $\begin{array}{l}9.1 \pm 5.3 \\
(91.0 \%)\end{array}$ & $\begin{array}{c}4.3 \\
15.0\end{array}$ \\
\hline Vitamin C (mg) & $60^{1}$ & $\begin{array}{l}{ }^{\mathrm{a}} 20.9 \pm 15.5 \\
(34.8 \%)\end{array}$ & $\begin{array}{l}12.2 \\
44.1\end{array}$ & $\begin{array}{c}{ }^{b} 37.3 \pm 17.1 \\
(62.1 \%)\end{array}$ & $\begin{array}{l}23.0 \\
57.2\end{array}$ & $75^{1}$ & $\begin{array}{c}\text { a } 25.8 \pm 15.1 \\
(34.4 \%)\end{array}$ & $\begin{array}{l}11.3 \\
41.6\end{array}$ & $\begin{array}{c}{ }^{\mathrm{b}} 36.5 \pm 17.5 \\
(48.6 \%)\end{array}$ & $\begin{array}{l}22.2 \\
57.3\end{array}$ \\
\hline Vitamin B6 (mg) & $1.3^{1}$ & $\begin{array}{l}\text { a } 0.9 \pm 0.3 \\
(69.2 \%)\end{array}$ & $\begin{array}{l}0.6 \\
1.2\end{array}$ & $\begin{array}{l}{ }^{\mathrm{b}} 1.2 \pm 0.3 \\
(96.1 \%)\end{array}$ & $\begin{array}{l}0.9 \\
1.6\end{array}$ & $1.4^{1}$ & $\begin{array}{l}1.3 \pm 0.2 \\
(92.8 \%)\end{array}$ & $\begin{array}{l}1.1 \\
1.6\end{array}$ & $\begin{array}{l}1.5 \pm 0.4 \\
(107.1 \%)\end{array}$ & $\begin{array}{l}1.2 \\
2.0\end{array}$ \\
\hline $\begin{array}{l}\text { Vitamin } \\
\text { B12 (meg) }\end{array}$ & $2.0^{1}$ & $\begin{array}{l}\mathrm{a} 1.1 \pm 0.6 \\
(55.0 \%)\end{array}$ & $\begin{array}{l}0.7 \\
1.9\end{array}$ & $\begin{array}{l}{ }^{\mathrm{b}} 1.6 \pm 0.7 \\
(80.0 \%)\end{array}$ & $\begin{array}{l}1.0 \\
2.5\end{array}$ & $2.0^{1}$ & $\begin{array}{l}2.1 \pm 1.4 \\
(105.0 \%)\end{array}$ & $\begin{array}{l}1.1 \\
4.0\end{array}$ & $\begin{array}{l}1.8 \pm 0.8 \\
(90.0 \%)\end{array}$ & $\begin{array}{l}1.1 \\
3.1\end{array}$ \\
\hline Folates (mcg) & $320^{1}$ & $\begin{array}{l}{ }^{\mathrm{a}} 91.3 \pm 30.5 \\
(28.5 \%)\end{array}$ & $\begin{array}{c}68.5 \\
130.2\end{array}$ & $\begin{array}{c}{ }^{\mathrm{b}} 127.5 \pm 34.0 \\
(39.8 \%)\end{array}$ & $\begin{array}{c}96.7 \\
165.4\end{array}$ & $320^{1}$ & $\begin{array}{c}130.5 \pm 33.5 \\
(40.7 \%)\end{array}$ & $\begin{array}{c}97.5 \\
165.4\end{array}$ & $\begin{array}{c}140.9 \pm 34.5 \\
(44.0 \%)\end{array}$ & $\begin{array}{l}108.1 \\
177.3\end{array}$ \\
\hline $\begin{array}{c}\alpha \text {-linolenic fatty } \\
\text { acid 18:3(n-3) (g) }\end{array}$ & $2^{2}$ & $\begin{array}{l}0.6 \pm 0.2 \\
(31.5 \%)\end{array}$ & $\begin{array}{l}0.3 \\
0.8\end{array}$ & $\begin{array}{l}0.7 \pm 0.3 \\
(35.0 \%)\end{array}$ & $\begin{array}{l}0.4 \\
1.1\end{array}$ & $2^{2}$ & $\begin{array}{l}1.1 \pm 0.5 \\
(55.0 \%)\end{array}$ & $\begin{array}{l}0.7 \\
1.8\end{array}$ & $\begin{array}{l}0.8 \pm 0.3 \\
(43.0 \%)\end{array}$ & $\begin{array}{l}0.6 \\
1.2\end{array}$ \\
\hline $\begin{array}{c}\text { EPA } 20: 5 \text { and DHA } \\
22: 6(\mathrm{n}-3)(\mathrm{mg})\end{array}$ & $200^{2}$ & $\begin{array}{l}0.0 \pm 21.5 \\
(0.0 \%)\end{array}$ & $\begin{array}{c}0.0 \\
43.0\end{array}$ & $\begin{array}{l}0.0 \pm 18.0 \\
(0.0 \%)\end{array}$ & $\begin{array}{c}0.0 \\
36.0\end{array}$ & $200^{2}$ & $\begin{array}{l}20.3 \pm 57.0 \\
(10.1 \%)\end{array}$ & $\begin{array}{c}0.0 \\
114.0\end{array}$ & $\begin{array}{l}15.0 \pm 28.5 \\
(7.5 \%)\end{array}$ & $\begin{array}{c}0.0 \\
57.6\end{array}$ \\
\hline
\end{tabular}

${ }^{1}$ EAR: estimated average requirement; ${ }^{2}$ Nutritional recommendation; ${ }^{3} \mathrm{AI}$ : adequate intake; Q1, Q3: quartiles 25, 75; Me: median; QD: quartile deviation $\mathrm{p}<$ 0.05 Mann-Whitney test; ${ }^{\mathrm{a}, \mathrm{b}}$ Statistical differences. 
Table 3. Biochemical parameters in elderly deviated into sex and MNA.

\begin{tabular}{|c|c|c|c|c|c|c|c|c|c|}
\hline \multirow{3}{*}{ Parameters } & \multirow{3}{*}{ References* } & \multicolumn{4}{|c|}{ Women $(n=630)$} & \multicolumn{4}{|c|}{$\operatorname{Man}(\mathrm{n}=371)$} \\
\hline & & \multicolumn{2}{|c|}{$\begin{array}{c}\text { At risk of } \\
\text { malnutrition }(n=45)\end{array}$} & \multicolumn{2}{|c|}{$\begin{array}{l}\text { Adequate nutritional } \\
\text { status }(\mathrm{n}=585)\end{array}$} & \multicolumn{2}{|c|}{$\begin{array}{c}\text { At risk of } \\
\text { malnutrition }(\mathrm{n}=18)\end{array}$} & \multicolumn{2}{|c|}{$\begin{array}{l}\text { Adequate nutritional } \\
\text { status }(\mathrm{n}=353)\end{array}$} \\
\hline & & $\mathrm{Me} \pm \mathrm{QD}$ & $\begin{array}{l}\text { Q1 } \\
\text { Q3 }\end{array}$ & $\mathrm{Me} \pm \mathrm{QD}$ & $\begin{array}{l}\text { Q1 } \\
\text { Q3 }\end{array}$ & $\mathrm{Me} \pm \mathrm{QD}$ & $\begin{array}{l}\text { Q1 } \\
\text { Q3 }\end{array}$ & $\mathrm{Me} \pm \mathrm{QD}$ & $\begin{array}{l}\text { Q1 } \\
\text { Q3 }\end{array}$ \\
\hline $\begin{array}{l}\text { Total cholesterol } \\
\qquad(\mathrm{mg} / \mathrm{dl})\end{array}$ & $<200$ & ${ }^{\mathrm{a}} 176.0 \pm 18.9$ & $\begin{array}{l}156.0 \\
193.0\end{array}$ & ${ }^{\mathrm{b}} 203.0 \pm 30.5$ & $\begin{array}{l}171.7 \\
233.0\end{array}$ & $195.2 \pm 39.5$ & $\begin{array}{l}174.4 \\
253.3\end{array}$ & $187.0 \pm 25.5$ & $\begin{array}{l}166.0 \\
217.4\end{array}$ \\
\hline $\begin{array}{l}\text { HDL-cholesterol } \\
\qquad(\mathrm{mg} / \mathrm{dl})\end{array}$ & $>50$ & $65.8 \pm 9.1$ & $\begin{array}{l}56.1 \\
74.3\end{array}$ & $63.4 \pm 9.5$ & $\begin{array}{l}54.4 \\
73.9\end{array}$ & $62.8 \pm 13.5$ & $\begin{array}{l}52.0 \\
79.9\end{array}$ & $56.4 \pm 11.3$ & $\begin{array}{l}45.8 \\
68.1\end{array}$ \\
\hline $\begin{array}{l}\text { LDL-cholesterol } \\
\qquad(\mathrm{mg} / \mathrm{dl})\end{array}$ & $<100$ & ${ }^{\mathrm{a}} 90.2 \pm 19.5$ & $\begin{array}{c}78.0 \\
117.0\end{array}$ & ${ }^{\mathrm{b}} 112.2 \pm 28.5$ & $\begin{array}{c}85.4 \\
142.4\end{array}$ & $120.0 \pm 34.5$ & $\begin{array}{c}52.0 \\
151.0\end{array}$ & $108.4 \pm 27,0$ & $\begin{array}{c}82.6 \\
137.0\end{array}$ \\
\hline Triglyceride (mg/dl) & $<150$ & ${ }^{\mathrm{a}} 85.0 \pm 27.9$ & $\begin{array}{c}64.1 \\
120.0\end{array}$ & ${ }^{b} 103.0 \pm 36.0$ & $\begin{array}{c}72.0 \\
146.0\end{array}$ & $103.0 \pm 30.4$ & $\begin{array}{c}75.0 \\
135.9\end{array}$ & $99.0 \pm 30.1$ & $\begin{array}{c}77.7 \\
138.0\end{array}$ \\
\hline Glucose (mg/dl) & $<100$ & ${ }^{\mathrm{a}} 89.9 \pm 8.2$ & $\begin{array}{l}80.0 \\
96.4\end{array}$ & ${ }^{\mathrm{b}} 93.0 \pm 10.5$ & $\begin{array}{c}84.0 \\
105.0\end{array}$ & ${ }^{\mathrm{a}} 103.9 \pm 9.0$ & $\begin{array}{c}97 \\
115.1\end{array}$ & ${ }^{\mathrm{b}} 96.0 \pm 9.0$ & $\begin{array}{c}87.1 \\
105.5\end{array}$ \\
\hline
\end{tabular}

"AHA Diet and Lifestyle Recommendations Revision 2006; Q1, Q3: quartiles 25, 75; Me: median; QD: quartile deviation p < 0.05 Mann-Whitney test; ${ }^{\mathrm{a}, \mathrm{b}}$ Statistical differences.

presented as Median $\pm \mathrm{QD}$, quartiles Q1, Q3 and were considered significant at $\mathrm{p}<0.05$.

\section{RESULTS}

\subsection{Subject Characteristics}

60 year old and older surveyed people comprised a group of participants of a prophylactic programme "Health of a Senior". The majority of the examined group lived in family homes $(77.7 \%)$, in a big city Wroclaw (49.4\%). One fifth of surveyed people lived alone. The assessment of nutritional status of elderly people was conducted using the MNA form that consisted of different questions as, for example, related to neuropsychological diseases. All participants declared the lack of this type of disease. 2 groups were distinguished using the MNA test: seniors at risk of malnutrition $(6.3 \%$ of total) and with an adequate nutritional status (93.7\%). In the group of participants with MNA in the range of 17 - 23.5 scores there were mainly women $(71.4 \%)$ from rural environments and over the age of 66 (84\%). This group statistically significantly more often had elementary education than people with an adequate nutritional status $(\mathrm{p}=0.00)$ (Table 1).

\subsection{Nutritional Assessment vs. MNA}

Nutritional status of people of every age is the basis for determination of their actual health condition and enables conducting a structural, biochemical and functional assessment of the body. According to an international definition, it is a status determined by habitual food intake, absorption and consumption of its nutrients and pathological factors that have impact on these processes. Assessment of nutritional status enables, for example: detection of nutritional deficits resulting from insufficient nutrient intake or improper absorption, and estimation of society's diseases exposure of aetiology that is strictly related to inadequate nutrition, in the aspect of both nutrient deficit and excess [12].

The intake of antioxidant and group B vitamins in food ratios by surveyed people is presented in Table 2 . According to suitable standards, the majority of surveyed people did not intake an adequate amount of vitamin A, E, C, B6, B12 and folates. This data was associated with generally low energetic value of all food ratios and a deficient intake of the basic food groups that were observed in the whole examined group of seniors. Additionally, in the group of women at risk of malnutrition a statistically significantly lower intake of all vitamins was observed than in the group of women with an adequate nutritional status. The intake of vitamin A was respectively $360.2 \mathrm{mcg}$ vs. $477.9 \mathrm{mcg}$ ( $\mathrm{p}<0.05$ ), of vitamin $\mathrm{E}$ $5.1 \mathrm{mg}$ vs. $6.4 \mathrm{mg}(\mathrm{p}<0.05)$. Particularly low intake of vitamin $\mathrm{C}$ was observed in the whole examined group of seniors; Q3 in the group of women and men with an adequate nutritional status was $57 \mathrm{mg}$. In the group of women at risk of malnutrition the intake of vitamin B12 was $1.1 \mathrm{mcg}$ (55\% of EAR standard) and was statistically significantly lower compared to the group of women with an adequate nutritional status $(1.6 \mathrm{mcg}, \mathrm{p}<$ 0.05 ). The content of folates in food ratios of seniors was very low and stated for around $40 \%$ of an accepted standard. Additionally, the lowest amounts of this vitamin were in the group of women at risk of malnutrition (91.3 $\mathrm{mcg}$, i.e. $28.5 \%$ of EAR).

The intake of polyunsaturated fatty acids $n-3$ in food ratios of surveyed seniors is also presented in Table 2. A very low intake of these nutrients was demonstrated, for which Q1 and Me in the group of women was zero. The Q3 value in the women group was about $40 \mathrm{mg}$ that 
stands for one fifth of recommended intake.

\subsection{Biochemical Parameters vs. MNA}

The assessment of lipid and carbohydrate metabolism parameters in blood serum of surveyed seniors was conducted and its results were presented in Table 3. Statistically significantly lower level of TC, LDL, TG and glucose (except HDL cholesterol) was revealed in the group of surveyed women at risk of malnutrition than in the group of women with an adequate nutritional status. However, in both groups these indicators were below accepted values (the exception was LDL level in the group of women with an adequate nutritional status$112.2 \mathrm{gl} / \mathrm{dl}$ ). In contrast, the highest values of measured parameters were revealed in the group of men with malnutrition and they were above limits for LDL (120.0 $\mathrm{mg} / \mathrm{dl}$ ). Regarding glucose level a statistically significant difference was demonstrated in the group of men at risk of malnutrition in comparison with the group of men with an adequate nutritional status (respectively 103.9 $\mathrm{mg} / \mathrm{dl}$ vs. $96.0 \mathrm{mg} / \mathrm{dl}, \mathrm{p}<0.05$ ).

\section{DISCUSSION}

In the last years the crucial role of inflammatory process and oxidative stress in pathomechanism of many chronic, non-infectious metabolic diseases, such as arteriosclerosis, diabetes, cancers and $\mathrm{AD}$ was documented. Free radicals that are being constantly formed, mostly in mitochondria, are very reactive, and attack all elements of cells. Antioxidant vitamins play a strategic role in removing oxidative stress from the body, and their inadequate consumption in the food (fruit, vegetables) may affect, among others, faster ageing process of the body and occurrence of inflammatory processes. The nerve tissue is particularly exposed to these processes due to the high oxygen consumption and increased mitochondrial density. An additional cause can be attributed to a low albumin level in cerebrospinal fluid and a significant concentration of polyunsaturated fatty acids in nerve cells membranes that easily undergo the process of peroxidation [13].

Among antioxidant vitamins, vitamin E plays an important role in prevention of these processes, because it prevents from a chain oxidation reaction of lipids that comprise cell membranes, but also from oxidation of LDL cholesterol that is responsible for the inflammatory process occurrence such as arteriosclerosis. This paper revealed a low intake of vitamin $\mathrm{E}$, which can lead to pathological changes in elderly people, as described above. Otrega et al. [14] investigated 110 people from 65 to 91 years of age and assessed their nutrition during 5 days. Additionally, the level of vitamin E in blood serum was determined. Surveyed people that consumed less than $50 \%$ of recommended amount of vitamin $\mathrm{E}$ in diet and that were characterised by a low level of vitamin $E$ in blood serum were making more errors in the mental test. Morris et al. [15] assessed the intake of vitamin E among 815 healthy people over the age 65 . Over the 3.9 years of studies it was demonstrated that the increases intake of dietary vitamin $\mathrm{E}$ was associated with lower risk of AD incidence. Particularly protective character of this relation was found among patients with no APOE 4 gene. It should be underlined that the intake of vitamin $\mathrm{C}$, beta-carotene and vitamin $\mathrm{E}$ in the form of diet supplements was not connected with lower risk of $\mathrm{AD}$ incidence. The intake of antioxidant vitamins was assessed among participants of the Rotterdam Study ( $\mathrm{n}=5395$, $>55$ years old). Over the 6 years of the study 197 cases of dementia were reported, among them 146 people were diagnosed with $\mathrm{AD}$. It was stated that the high intake of vitamins $\mathrm{C}$ and $\mathrm{E}$ was associated with the low risk of $\mathrm{AD}$, independently of education level and the presence of the APOE 4 genotype [16].

Vitamins such as B6, B12 and folates play the important role in an adequate metabolism of homocysteine amino acid. This amino acid is an intermediate compound between ergogenic methionine and endogenic cysteine, and is also a recognized risk factor for cardiovascular diseases. Blood vessels damages, in particular of the brain, due to increased homocysteine level in blood serum can indirectly affect $\mathrm{AD}$ incidence, velocity of $\beta$-amyloid deposits accumulation in nerve tissue and the extent to which they get to the blood. Ischemia caused by narrowing of brain microvessels can also stimulate amyloidogenesis, and increase the risk of Alzheimer's dementia incidence [17]. One of the important elaboration confirming the relation between hyperhomocysteinemia and $\mathrm{AD}$ was the Framingham Study that determined the level of homocysteine in blood serum in elderly people $(>70 \pm 7$ years, $\mathrm{n}=1947)$ over the period of twenty years [18]. It was demonstrated that the level of this parameter above $14 \mu \mathrm{mol} / 1$ was significantly associated with twice as much risk of $\mathrm{AD}$ incidence, and every increase of $5 \mu \mathrm{mol} / 1$ increased the risk of $40 \%$. The elderly people with the constant increase of the homocysteine level since the beginning of studies were more exposed to $\mathrm{AD}$ incidence. It was possible to predict this risk as far back as 8 years before the first occurrence of symptoms. British studies OPTIMA (Oxford Project to Invastigate Memory and Aging) demonstrated the high level of homocysteine and the low level of vitamin B12 and folic acid in patients with $\mathrm{AD}$, independently of sex, age, social status and smoking habits. In the follow up study conducted after 3 years, the faster disease progression was noticed in the examined group of people with higher initial homocysteine level in the blood [19]. Corrada et al. assessed nutrition status of 579 participant 
( $>60$ years of age) of the Baltimore Longitudinal Study of Aging. Over the 9 years of the study, it was demonstrated that 57 patients suffer from AD. The significant relation between the high intake of folates (much above RDA) and decrease of risk of AD incidence was found. For vitamins: C, B12 and carotenoids, this correlation was not demonstrated [20].

The low intake of folates, vitamins: B6 and 12 in the diet of elderly people was demonstrated in this study as well as in many others, independently of age, sex, education level, place of residence [12,21-23]. It should be underlined that a physiological reduction of hydrochloric acid and digestive enzyme secretion in the stomach and pancreas, which was observed in elderly people, additionally results in decreased absorption of vitamin B12. Moreover, if anthropic changes of gastric mucosa appear, dysfunction of the bonding of this vitamin to the internal factor IF and the impairment of its absorption will occur [24].

Additionally, folates are characterised by a significant sensitivity to temperature. The treatment of the food that is their source in diet (green vegetables: broccoli, spinach, brussels sprouts) leads to as much as even a $70 \%$ loss of this vitamin in food sources.

Population studies demonstrated that the high intake of LC-PUFA n-3 deriving from fish oils as well as see fish was associated with a reduced occurrence of ischemic heart disease, myocardial infarction and stroke, but potentially it can be associated with a reduced occurrence of $\mathrm{AD}$ due to vessels mechanisms [25-27]. An impact of fish and meat intake frequency on dementia risk was assessed in the study PAQUID (Personnes Agées QUID) in the group of 1416 elderly people from France $(>68$ years of age). Over the 7 years of studies, a statistically lower risk of dementia incidence, included $\mathrm{AD}$, was demonstrated among participants that were consuming fish or see fruit at least 1 a week. The authors highlighted that dementia symptoms among surveyed people had been found 3 years before diagnosis was made and its risk could have been influenced by improper nutrition habits [28]. Fish consumption was assessed among 815 healthy participants of the Chicago Health and Aging Project from 65 to 94 years of age. Over the 2.3 years of the study, 131 of surveyed people came down with AD. It was demonstrated that among patients eating fish at least 1 a week or more often the risk of $\mathrm{AD}$ was lowered to $60 \%$ in comparison to people who were consuming fish rarely or not at all [29].

In this study and in many other countries, consumption of fish as a source of LC-PUFA among elderly people is insufficient. Scientific researches regarding using EPA + DHA supplements in the prophylaxis of degenerative diseases in elderly people are still missing. However, it seems that recently modified recommendations about their consumption fulfil aim of prophylaxis, not only for cardiovascular diseases, but also neuropsychological diseases [30].

Eating is nothing else but providing the man's organism with food in the natural state or in the processed form, securing its basic life function. In order to function properly, it is necessary to eat food regularly, everyday, and the food should have the composition of the right quality, as well as the proper quantity and hygienic requirements. Eating is one of the few joys in man's life, especially in life of an elder person. It may also serve a function of the so-called "protective factor", but also become an additional negative stressor. Therefore, principles of appropriate selection of food products that would provide adequate quantities of all nutrients indispensable for health, especially B-group vitamins, antioxidative vitamins and polyunsaturated fatty acids, should be widely propagated.

\section{ACKNOWLEDGEMENTS}

We would like to express our gratitude to Mrs. Dorota Kiedik-director of the Institute of Public Health of the city of Wroclaw and Mr. Marcin Kasina-borough leader of the Oleśnica district, for logistic help and financial support of the research.

\section{REFERENCES}

[1] Cannella, C., Savina, C. and Donini, L.M. (2009) Nutrition, longevity and behavior. Archives Gerontology and Geriatrics, 1, 19-27. doi:10.1016/j.archger.2009.09.008

[2] Pirlich, M. (2001) Nutrition in the elderly. Best Practice and Reserch Clinical Gastroenterology, 15, 869-884. doi:10.1053/bega.2001.0246

[3] Lakhan, S.E. and Vieira, K.F. (2008) Nutritional therapies for mental disorders. Journal of Nutrtion, 7, 2-10. doi:10.1186/1475-2891-7-2

[4] World Health Organization (2010) Setting priorities for global mental health research.

[5] Kisvetrova, H., Spirudova, L. and Grochowska-Niedworok E. (2010) Nutrition problems of elderly people in the Czech Republic. Polish Journal of Environmental Studies, 19, 29-32.

[6] Bährer-Kohler, S. (2012) Social determinations and mental health. Nova Science Publishers, Inc., New York.

[7] Kunachowicz, H. Nadolna, I. Przygoda, B. and Iwanow, K. (2005) Food composition tables. PZWL, Warsaw.

[8] Jarosz, M. and Bułchak-Jachymczyk, B. (2008) Normy żywienia człowieka. Podstawy prewencji otyłości i chorób niezakaźnych. PZWL, Warsaw (in Polish).

[9] Cohendy, R. Gros, T. Arnaud-Battandier, F. Tran, G. Plaze, J.M. and Eledjam, J.J. (1999) Preoperative nutritional evaluation of elderly patients: The mini nutritional assessments a practical tool. Clinical Nutrition, 18, 345348. 
[10] Vellas, B. Guigoz, Y. Garry, P.J. Nourhashemi, F. and Bennahum, D. (1999) The mini nutritional assessment (MNA) and its use in grading the nutritional state of elderly patients. Nutrition, 15, 116-122. doi:10.1016/S0899-9007(98)00171-3

[11] AHANC (American Heart Association Nutrition Committee), Lichtenstein, A.H., Appel, L.J., Brands, M., Carnethon, M., Daniels, S., Franch, H.A., Franklin, B., KrisEtherton, P., Harris, W.S., Howard, B., Karanja, N., Lefevre, M., Rudel, L., Sacks, F., Van Horn, L., Winston, M. and Wylie-Rosett, J. (2006) Diet and lifestyle recommendations revision 2006: A scientific statement from the American Heart Association Nutrition Committee. Circulation, 114, 82-96. doi:10.1161/CIRCULATIONAHA.106.176158

[12] Volkert, D. (2005) Nutrition and lifestyle of elderly in Europe. Journal of Public Health, 13, 56-61. doi:10.1007/s10389-004-0092-8

[13] Raats, M., De Groot, L. and Van Staveren, W. (2009) Food for the ageing population. Woodhead Publishing Limited, Cambridge.

[14] Otrega, R.M., Requejo, A.M., Lopez-Sobaler, A.M. and Andres, P. (2002) Cognitive function in elderly people is influenced by vitamin E status. Journal of Nutrition, 132, 2065-2068.

[15] Morris, M.C., Evans, D.A. and Bienias, J.L. (2002) Dietary intake of antioxidant nutrients and the risk of incident Alzheimer diseases in a biracial community study. Journal of American Medical Association, 287, 32303237. doi:10.1001/jama.287.24.3230

[16] Engelhart, M.J., Geerlings, M.I., Ruitenberg, A. and Van Swieten, A. (2002) Dietary intake of antioxidants and risk of Alzheimer disease. Journal of American Medical Association, 287, 3223-3229. doi:10.1001/jama.287.24.3223

[17] Fudala, M., Brola, W., Przybylski, W. and Czernicki, J. (2008) Is research in homocysteine and cyanocobalamine levels likely to become the key to diagnosing and treating Alzheimer diseases? Medical Study, 10, 53-58.

[18] Bostom, A.G., Rosenberg, I.H. and Silbershatz, H. (1999) Nonfasting plasma total homocysteine levels and stroke incidence in elderly persons: The Framingham study. $A n$ nales of Internal Medicine, 131, 352-355.

[19] Köseoglu, E. and Karaman, Y. (2007) Relations between homocysteine, folate and vitamin B12 in vascular dementia and in Alzheimer disease. Clinical Biochemistry, 40, 859-863. doi:10.1016/j.clinbiochem.2007.04.007

[20] Corrada, M.M., Kawas, C.H., Hallfrisch, J., Muller, D. and Brookmeyer, R. (2005) Reduced risk of Alzheimer's disease with high folate intake: The Baltimore longitudinal study of aging. Alzheimer's \& Dementia, 1, 11-18. doi:10.1016/j.jalz.2005.06.001

[21] Haveman-Nies, A., Tucker, K.L. and de Groot, L. (2001) Evaluation of dietary quality in relationship to nutritional and lifestyle factors in elderly of the US Framingham heart study and the European SENECA study. Journal of Clinical Nutrition, 55, 870-880. doi:10.1038/sj.ejen.1601232

[22] Wyka, J., Biernat, J. and Kiedik, D. (2010) Nutritional determination of the health status in polish elderly people from an urban environment. Journal of Nutrition, Health and Aging, 14, 67-71. doi:10.1007/s12603-010-0012-2

[23] Wyka, J., Biernat, J., Mikołajczak, J. and Piotrowska, E. (2012) Assessment of dietary intake and nutritional status (MNA) in Polish free-living elderly people from rural environments. Archives of Gerontology and Geriatrics, 54, 44-49. doi:10.1016/j.archger.2011.02.001

[24] Saunier, K. and Dore, J. (2002) Gastrointestinal tract and the elderly: Functional foods, gut microflora and healthy aging. Digestive Liver Disease, 34, 19-24. doi:10.1016/S1590-8658(02)80158-X

[25] Bucher, H.C. (2002) Polyunsaturated fatty acids in coronary heart disease: Meta analysis of randomized controlled trials. American Journal of Medicine, 112, 298304. doi:10.1016/S0002-9343(01)01114-7

[26] Hu, F.B. (2002) Fish and omega n-3 fatty acid intake and risk of coronary heart disease in woman. Journal of American Medical Association, 287, 1815-1821. doi:10.1001/jama.287.14.1815

[27] Mozaffarian, D. (2005) Fish consumption and stroke risk in elderly individuals: The cardiovascular health study. Archives of Internal Medicine, 165, 200-206. doi:10.1001/archinte.165.2.200

[28] Barberger-Gateau, P., Letenneur, L. and Deschamps, V. (2002) Fish, meat and risk of dementia: Cohort study. British Medical Journal, 325, 932-933. doi:10.1136/bmj.325.7370.932

[29] Morris, M.C., Evans, D.A. and Bienias, J.L. (2003) Consumption of fish and n-3 fatty acids and risk of incident Alzheimer disease. Archives of Neurology, 60, 940-946. doi:10.1001/archneur.60.7.940

[30] Kris-Etherton, P.M. and Hill, A.M. (2008) N-3 fatty acids: Food or supplements? Journal of American Dietetic Association, 108, 1125-1130. doi:10.1016/j.jada.2008.04.025 